\title{
Primary Mucoepidermoid Carcinoma of the Lacrimal Sac - a Case Report and Literature Review
}

\author{
Primární mukoepidermoidní karcinom slzného vaku - \\ kazuistika a přehled literatury
}

\author{
Janakiram T. N. ${ }^{1}$, Sagar S. ${ }^{1}$, Sharma S. B. ${ }^{1}$, Subramaniam V. ${ }^{2}$ \\ 1 Head and Neck Surgery Department, Royal Pearl Hospital, Tiruchirappalli, Tamil Nadu State, India \\ ${ }^{2}$ Department of Otorhinolaryngolgy, Yenepoya Medical College, Yenepoya University Campus, Deralakatte, Mangalore, Karnataka State, India
}

\begin{abstract}
Summary
Background: Lacrimal sac tumors are very rare and are often missed because patients present with features consistent with chronic dacryocystitis. Squamous cell carcinoma is the commonest lacrimal sac malignancy. Although primary mucoepidermoid carcinomas of the lacrimal sac are rare, they are locally aggressive. Furthermore, their proximity to vital structures and the skull base makes them potentially life-threatening. Multidisciplinary management is required, and wide excision followed by chemoradiation is the recommended treatment. Case: Here, we report a 65 -year-old male who presented with watering eyes and a mass in the region of the medial canthus. A diagnosis of primary mucoepidermoid carcinoma of the lacrimal sac was made, and the case was managed successfully with radical surgery and reconstruction. The tumor was resected using the extended Lynch-Howarth incision and the resulting defect was reconstructed using a forehead flap. Histopathological examination of the excised specimen revealed mucoepidermoid carcinoma. Immunohistochemical analysis revealed that the specimen was positive for epithelial growth factor receptor and Ki-67 protein. The patient was referred for post-operative chemoradiation. The literature is reviewed and pathological features, including immunohistochemistry are discussed. Conclusion: Primary mucoepidermoid carcinoma of the lacrimal sac is a rare, locally aggressive tumor that is often mistaken for dacryocystitis. The treatment of choice is radical surgery followed by chemoradiation.
\end{abstract}

Key words

lacrimal sac - mucoepidermoid carcinoma - epithelial growth factor receptor - Ki-67 protein

\section{Souhrn}

Východiska: Nádory slzného vaku jsou velmi vzácné a jsou často nerozpoznány, jelikož pacienti mají zdánlivě chronickou dakryocystitidu. Jako nejčastější se u nádorů slzného vaku uvádí karcinom dlaždicových buněk. Primární mukoepidermoidní karcinomy slzného vaku jsou vzácné a jsou popisovány jako lokálně agresivní. Navíc jejich blízkost životně důležitým strukturám a bazi lebeční je činí potenciálně život ohrožující. Doporučuje se multidisciplinární přístup se širokým vyříznutím s následnou chemoradiací. Prípad: Popisujeme prípad primárního mukoepidermoidního karcinomu slzného vaku u 65letého muže. Karcinom se projevoval slzením očí a prítomností hmoty v oblasti mediálního koutku, kterou se úspěšně podařilo odstranit radikální operací a rekonstrukcí. Nádor byl resekován pomocí rozšiřeného Lynch-Howarthova řezu a defekt byl odstraněn za použití čelní klapky. Histopatologické vyšetření vyříznutého vzorku odhalilo mukoepidermoidní karcinom. Imunohistochemické barvení bylo pozitivní na EGFR (receptor pro epiteliální růstový faktor) a Ki-67 protein. Pacient byl po operaci odeslán $\mathrm{k}$ chemoradiaci. V tomto článku byla shrnuta literatura a jsou diskutovány patologické rysy vč. imunohistochemie. Závěr: Primární mukoepidermoidní karcinom slzného vaku je vzácný, lokálně agresivní nádor, který je často mylně považován za dakryocystitidu. Léčebnou modalitou je radikální operace a následně chemoradiace.

\section{Klíčová slova}

slzný vak - mukoepidermoidní karcinom - receptor pro epiteliální růstový faktor - Ki-67 protein

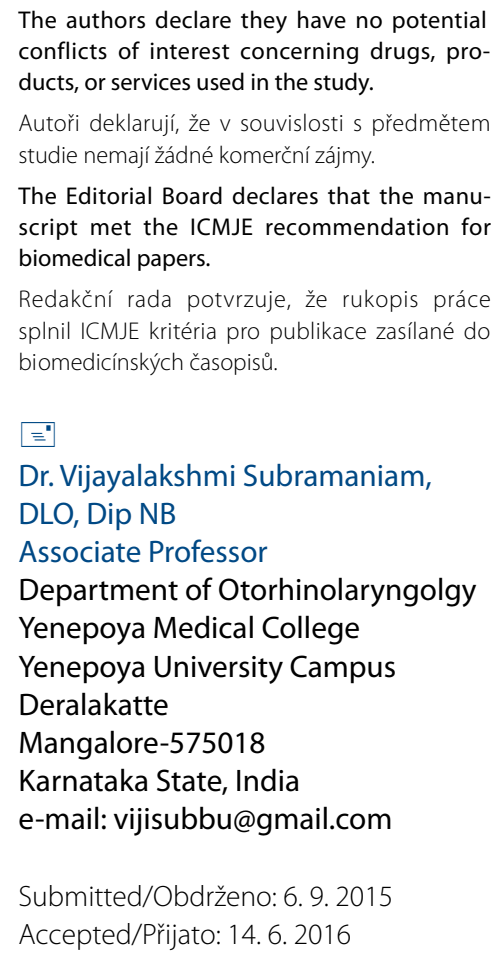

The authors declare they have no potential conflicts of interest concerning drugs, products, or services used in the study.

Autoři deklarují, že $v$ souvislosti s predmětem studie nemají žádné komerční zájmy.

The Editorial Board declares that the manuscript met the ICMJE recommendation for biomedical papers.

Redakční rada potvrzuje, že rukopis práce spInil ICMJE kritéria pro publikace zasílané do biomedicínských časopisů.

$\equiv$

Dr. Vijayalakshmi Subramaniam,

DLO, Dip NB

Associate Professor

Department of Otorhinolaryngolgy Yenepoya Medical College Yenepoya University Campus Deralakatte

Mangalore-575018

Karnataka State, India

e-mail: vijisubbu@gmail.com

Submitted/Obdrženo: 6. 9. 2015

Accepted/Přijato: 14. 6. 2016

http://dx.doi.org/10.14735/amko2016291 


\section{Introduction}

Primary lacrimal passage malignancies are very uncommon [1-3]. Only 400 cases have been reported in the literature so far with most being epithelial tumors. Previous studies have reported squamous cell carcinoma to be the most common, followed by transitional cell and rarely adenocarcinoma, adenocystic carcinoma and mucoepidermoid carcinoma [2,5-8]. Non-epithelial mesenchymal tumors are also very rare. Lacrimal sac tumors usually present as chronic dacryocystitis and are often missed. They are conservatively managed until late stages. Therefore, awareness of symptoms, high index of suspicion and proper clinical examination with imaging and biopsy are recommended for confirmation of diagnosis [5]. These tumors are potentially life-threatening due to proximity to vital structures and skull base. Multidisciplinary management comprising wide surgical excision followed by radiotherapy and targeted adjuvant chemotherapy is optimal to prevent recurrences and metastases.

\section{Case Report}

A 65-year-old male presented with a mass (lump) in the left medial canthus with watering of eye of three months duration. Patient had consulted an ophthalmologist and was treated for dacryocystitis with antibiotics for one month. The swelling grew in size and became hard. The patient reported to the out-patient department at our hospital with a mass in close proximity to the left medial canthus. It was $2-3 \mathrm{~cm}$ in size, firm to hard in consistency and non-tender. There were no palpable cervical lymph nodes. Biopsy of the mass was suggestive of mucoepidermoid carcinoma. Computerized tomography (CT) scan showed a heterogeneous irregular non-calcified mass approximately $2.3-2.6 \mathrm{~cm}$ in size with extension into the nasolacrimal duct (Fig. 1). Nasal endoscopy revealed only bulge in the lacrimal sac area. Total resection of the tumor was planned followed by reconstruction using forehead flap.

Under General Anesthesia, extended Lynch-Howarth incision was given starting from mid-point between medial canthus and nasal bridge extending downwards and turning inferiorly along

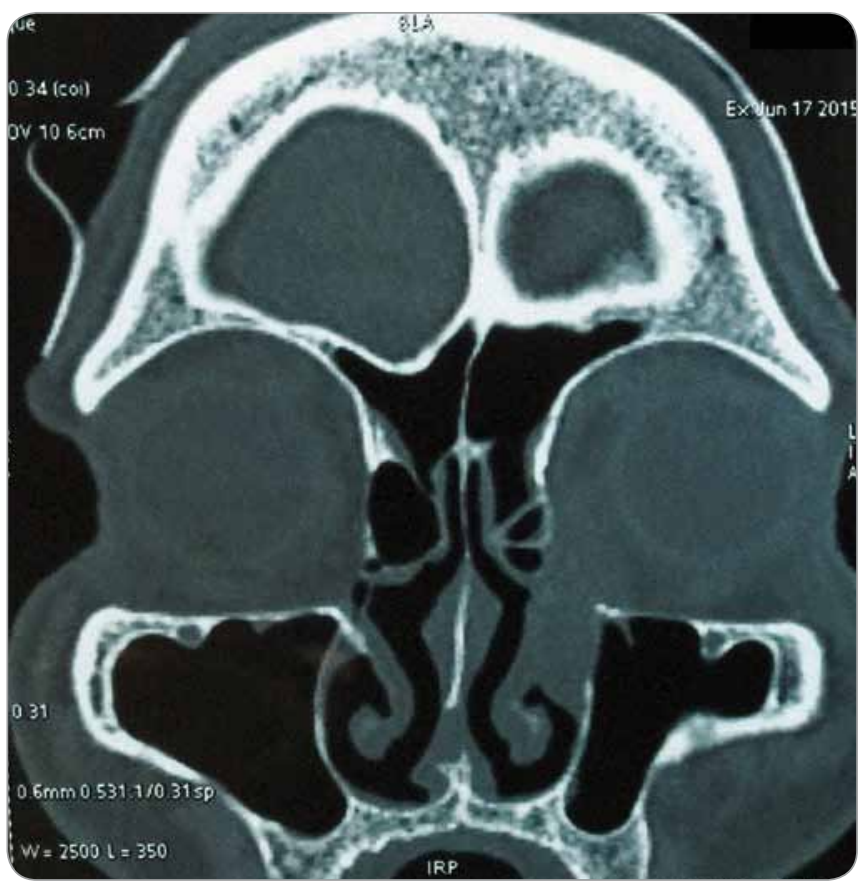

Fig. 1. CT scan showing heterogeneous irregular non-calcified mass approximately $2.3-2.6 \mathrm{~cm}$ in size with extension into the nasolacrimal duct. the swelling taking $0.5 \mathrm{~cm}$ tumor free margin. Incision was deepened until the bone and the periorbita was raised. Periorbita was uninvolved by the tumor. Frontal process of maxilla, lacrimal bone and lamina papyracea were drilled to delineate the tumor. Anterior Ethmoidectomy was done and the tumor was resected in toto.

A frozen section of the specimen was sent to confirm non-involvement of the eye. Eye was found to be free of the tumor. Defect was repaired with paramedian forehead flap (Fig. 2). Histopathological examination of the excised specimen showed large polygonal cells forming nests and occasional glandular structure. The cells had round, hyperchromatic pleomorphic nuclei and abundant eosinophilic cytoplasm. Focally, the cells also showed cytoplasmic keratinization (Fig. 3). The tumor was infil-

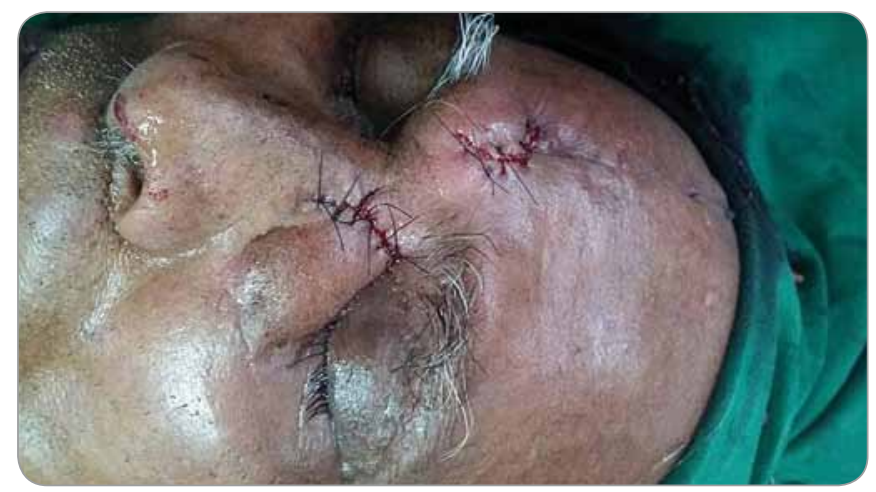

Fig. 2. Clinical photograph taken after wide excision of lesion and reconstruction with median forehead flap.

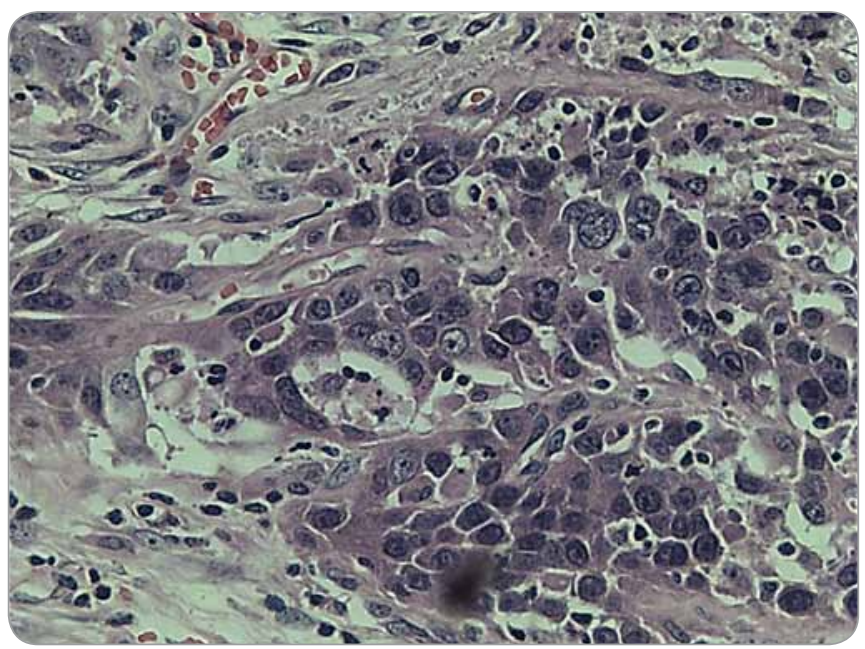

Fig. 3. Microphotograph of the excised specimen showed large polygonal cells with round, hyperchromatic pleomorphic nuclei forming nests and occasional glandular structure (H \& E stain). 


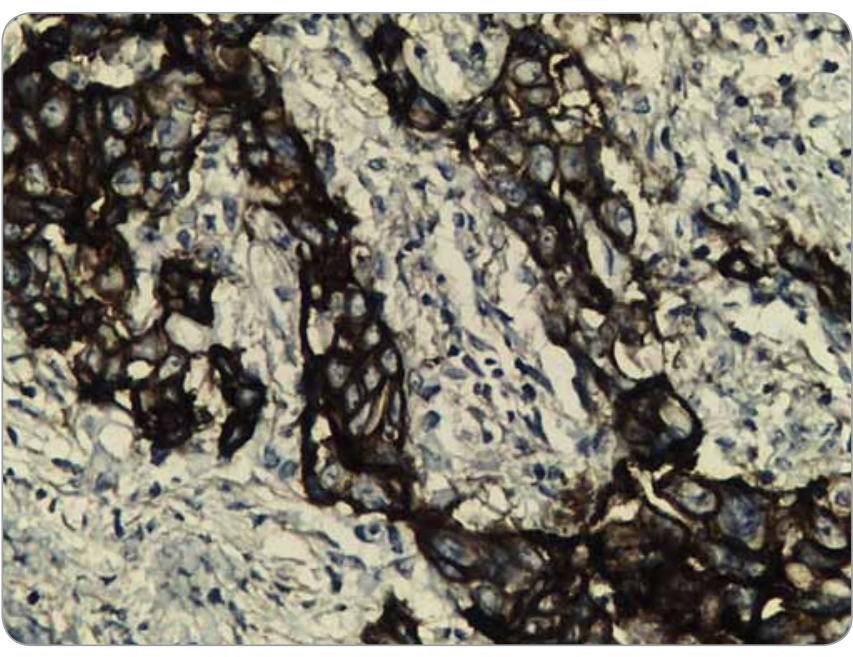

Fig. 4. Immunohistochemistry photograph showing positive immunoreactivity for EGFR.

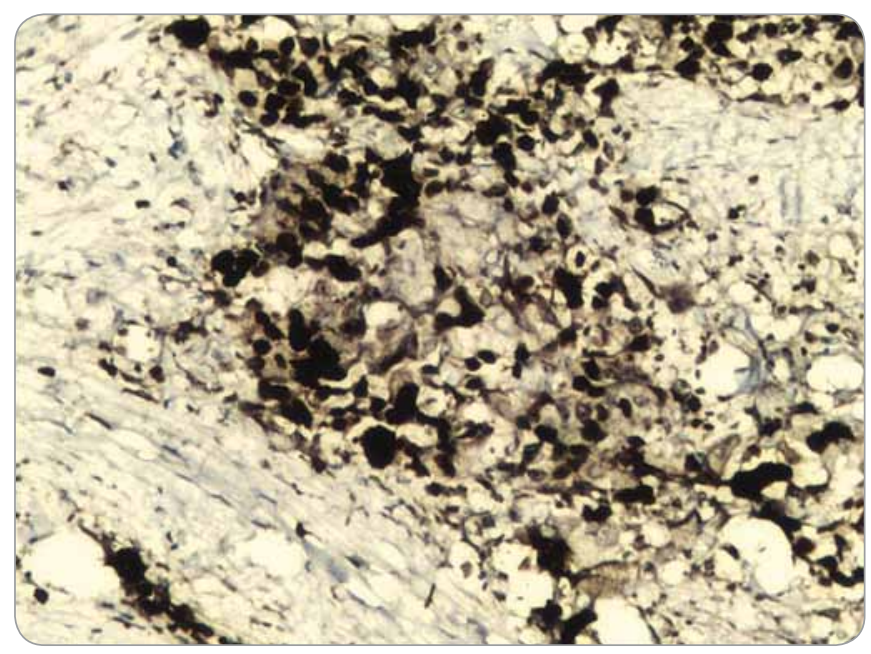

Fig. 5. Immunohistochemistry photograph showing positive immunoreactivity for Ki-67 and MIB-1 labelling index of $80 \%$. trating the surrounding fibromuscular tissue with vascular emboli. Margins of the excised specimen were free of tumour. Immunohistochemical staining was positive for epithelial growth factor receptor (EGFR) (Fig. 4) and Ki-67 protein. Mitotic rate was 30/10 per high power field with MIB-1 labelling index of $80 \%$ (Fig. 5). The flap took up well and patient was referred for chemoradiation.

\section{Discussion}

A case of primary mucoepidermoid carcinoma of the lacrimal sac is reported here. The diagnosis of primary mucoepidermoid carcinoma in this case was made considering the absence of any pathology in the salivary glands. Mucoepidermoid carcinoma is a relatively rare malignancy which is commonly seen in salivary glands, mostly in parotid (60-70\%). Serous and mucus units similar to those in salivary glands have been observed in the lacrimal sac. Malignancies similar to salivary glands have been documented in lacrimal sac too [9-12]. The origin of mucoepidermoid carcinoma of the lacrimal sac is postulated to be from the ductal epithelium located in the fundus of the lacrimal sac [4]. Primary mucoepidermoid carcinoma of lacrimal sac is extremely rare. Only 14 cases have been reported in the literature. The first case was described in 1981 by Bambirra et al. in Brazil [13]. Our analysis revealed that the primary mucoepidermoid carcinoma predominantly affects males between $40-60$ years. The diagnosis of mucoepidermoid carcinoma requires the existence of three type of cells, namely epidermoid, intermediate and mucin secreting cells with mucin filled cystic spaces [14]. The tumors are graded on the basis of the histological pattern into high-grade and low-grade. High-grade tumors are comprised of mainly epidermoid cells and sparse mucin producing cells whereas the low-grade tumors have a large number of mucin producing cells with sparse epidermoid cells. The characteristic histological feature of this tumor is mucin production. The histopathological features of the present case were large polygonal cells forming nests and occasional glandular structure. The cells had round hyperchromatic pleomorphic nuclei and abundant eosinophilic cytoplasm. Focally, the cells also showed cytoplasmic keratinization. Although the tumor was seen to be infiltrating the surrounding fibromuscular tissue with presence of vascular emboli, the resected specimen margins were free of the tumor. The current standard of treatment for these tumors includes surgical excision followed by radiotherapy or chemoradiotherapy. Due to proximity to orbit and skull base, the treatment of carcinoma of lacrimal sac necessitates a wide surgical excision. The decision for orbital exentration is individualized and is based on orbital tissue infiltration by the tumor. Some practitioners prefer exen- tration because of concern of local recurrence and also damage by radiotherapy if the eye is spared [15-17]. A study comprising 71 cases of lacrimal sac carcinoma showed mortality rate to be $43.7 \%$ despite orbital exentration and radical treatment.

It was also observed that once a tumor extends beyond the lacrimal sac wall into the orbit, orbital exentration with radical approach does not change or improve the prognosis [4].

The treatment modality of different histological tumors might be same but there is a possibility of receptor marker expression in specific tumors, which might open the possibility of targeted adjuvant chemotherapy [3]. Targeted adjuvant chemotherapy for these tumors is still an experimental approach. In this case, positive immunoreactivity for epithelial growth factor receptor (EGFR) and $\mathrm{Ki}-67$ protein (Ki-67) along with mitotic rate 30/10 high power field (HPF), with MIB-1 labelling Index of $80 \%$ was found, which indicated constant activation and uncontrolled cell division, thus grading the tumor as high-grade mucoepidermoid carcinoma. P53 was positive in few cells, indicating good prognosis. High molecular weight cytokeratin and low molecular weight cytokeratin were focally positive in many cells. Cytokeratin 7 (CK7) was found to be negative, which is mostly seen in adenocarcinoma. Her2/neu which is seen in breast cancer, salivary glands and gastric mali- 
gancies was also negative. In one of the studies Her2/neu expression in adenocarcinoma justified the use of trastuzumab in the adjuvant systemic treatment. Similarly in another study, a patient was treated with EGFR inhibitor erlotinib as a part of regimen for treatment of metastatic disease. The patient was earlier treated with carboplatin and docetaxel, but developed recurrence [18]. In this case, mTOR was negative. There is evidence of $\mathrm{mTOR}$ pathway proteins in adenocarcinoma. mTOR is a serine/threonine kinase that regulates cell growth and metabolism. Activation of mTOR and its regulatory proteins have been reported in various tumors that makes mTOR inhibitor to be a promising therapeutic agent in the treatment [19-23]. The possibility of receptor marker expression in individual tumor may open up the options of target oriented systemic treatment along with radiotherapy to prevent recurrence.

The preferred approach should always be multidisciplinary consisting of a wide surgical excision if possible with reconstruction followed by targeted adjuvant chemotherapy and radiotherapy to prevent recurrences and metastases. Continued follow-up should include careful clinical examination of orbit and nose. Radio imaging i.e CT scan or MRI of head and neck every three months for a year, half yearly during second year is recommended after the treatment of lacrimal sac malignancy for optimum results [18].

The presented case was managed by surgical excision and reconstruction using a median forehead flap. Patient was referred for chemoradiation thereafter. No tumor recurrence has been observed after two-month follow-up.

\section{Conclusion}

Primary mucoepidermoid carcinomas of the lacrimal sac are extremely rare and often masquerade as dacryocystitis and hence are managed conservatively. Being locally aggressive, these tumors need to be treated with radical surgery. Histopathology with immunohistochemistry clinches the diagnosis.

\section{References}

1. Parmar DN, Rose GE. Management of lacrimal sac tumours. Eye (Lond) 2003: 17(5): 599-606.

2. Stefanyszyn MA, Hidayat AA, Pe'er JJ et al. Lacrima sac tumours. Ophthal Plast Reconstr Surg 1994; 10(3): 169-184.

3. Hornblass A, Jakobiec FA, Bosniak S et al. The diagnosis and management of epithelial tumours of the lacrimal sac. Ophthalmology 1980; 87(6): 476-490.

4. Ni C, D'Amico DJ, Fan CQ et al. Tumours of the lacrima sac: a clinicopathological analysis of 82 cases. Int Ophthatmol Clin 1982; 22(1): 121-140.

5. Islam S, Thomas A, Eisenberg RL et al. Surgical management of transitional cell carcinoma of the lacrima sac: is it time for a new treatment algorithm? J Plast Reconstr Aesthet Surg 2012; 65(2): e33-e36. doi: 10.1016/j. bjps.2011.09.029.

6. Low JR, Bian Ng S, Sundar G. Undifferentiated carcinoma of the lacrimal sac: case report and re view of literature. Orbit 2011; 30(6): 293-296. doi 10.3109/01676830.2011.615458

7. Lee LN, Scott AR, Chan AW et al. Management of transitional cell carcinoma of the lacrimal sac: a multidisciplinary approach to orbit sparing treatment. Laryngoscope 2010; 120 (Suppl 4): S161. doi: 10.1002/lary.21625.

8. Lee SB, Kim KN, Lee SR et al. Mucoepidermoid carcinoma of the lacrimal sac after dacryocystectomy for squamous papilloma. Ophthal Plast Reconstr Surg 2011; 27(2): e44-e46. doi: 10.1097/IOP.0b013e3181eea4e4.

9. Montalban A, Lietin B, Louvrier C et al. Malignant lacrimal sac tumours. Eur Ann Otorhinolaryngol Head Neck
Dis 2010; 127(5): 165-172. doi: 10.1016/j.anorl.2010.09. 001

10. Pe'er J, Hidayat AA, Ilsar M et al. Glandular tumours of the lacrimal sac. Their histopathologic patterns and possible origins. Ophthalmology 1996; 103(10): 1601-1605

11. Stefanyszyn MA, Hidayat AA, Pe'er JJ et al. Lacrimal sac tumours. Ophthal Plast Reconstr Surg 1994; 10(3): 169-184.

12. Ishida M, Mori T, Umeda T et al. Pleomorphic lobular carcinoma in a male breast: case report with review of the literature. Int J Clin Exp Pathol 2013; 6(7): 1441-1444.

13. Bambirra EA, Miranda D, Rayes A. Mucoepidermoid tumour of the lacrimal sac. Arch Ophthalmol 1981; 99(12): 2149-2150

14. Fliss DM, Freeman JL, Hurwitz JJ et al. Mucoepidermoid carcinoma of the lacrimal sac: a report of two cases, with observations on the histogenesis. Can J Ophthalmol 1993; 28(5): 228-235.

15. Schenck NL, Ogura JH, Pratt LL. Cancer of the lacrimal sac. Presentation of five cases and review of the literature Ann Otol Rhinol Laryngol 1973; 82(2): 153-161.

16. Ryan SJ, Font RL. Primary epithelial neoplasms of the lacrimal sac. Am J Ophthalmol 1973; 76(1): 73-88.

17. Heindl $L M$, Jünemann AG, Kruse FE et al. Tumours of the lacrimal drainage system. Orbit 2010; 29: 298-306. doi: 10.3109/01676830.2010.492887.

18. El-Sawy T, Frank SJ, Hanna E et al. Multidisciplinary management of lacrimal sac/nasolacrimal duct carcinomas. Ophthal Plast Reconstr Surg 2013; 29(6): 454-457. doi: 10.1097/IOP.0b013e31829f3a73.

19. Dobashi Y, Watanabe Y, Miwa C et al. Mammalian target of rapamycin: a central node of complex signaling cascades. Int J Clin Exp Pathol 2011; 4(5): 476-495.

20. Ueng SH, Chen SC, Chang YS et al. Phosphorylated mTOR expression correlates with poor outcome in early-stage triple negative breast carcinomas. Int J Clin Exp Pathol 2012; 5(8): 806-813.

20. Li N, Zhong M, Song M. Expression of phosphorylated mTOR and its regulatory protein is related to biological behaviors of ameloblastoma. Int J Clin Exp Pathol 2012; 5(7): 660-667.

21. Ishida M, Okabe H. Dedifferentiated adenoid cystic carcinoma of the trachea: a case report with respect to the immunohistochemical analyses of mammalian target of rapamycin pathway proteins. Hum Pathol 2013; 44(8): 1700-1703. doi: 10.1016/j.humpath.2012.12.015.

22. Ishida $M$, Okabe $H$. Expression profiles of mTOR pathway proteins in porocarcinoma: a provisional immunohistochemical study. Biomed Rep 2013; 1(1): 28-30 